\title{
THE EFFECT OF HYPOXAEMIA ON THE CEREBRAL BLOOD FLOW OF THE DOG UNDER METHOXYFLURANE ANAESTHESIA *
}

\author{
Samir K. Mitra, Iain G. Gray, Hugh I. A.Nisbet, Robert E. Creighton and \\ Norman Aspin, with the technical help of George Volgyesi
}

THE FFFECT OF HYPOXAemia upon the cerebral blood flow (CBF) has been studied in anaesthetised animals, ${ }^{1-3}$ but only intravenous anaesthetic agents, usually pentobarbitone, have been investigated. No studies have been made of the effect of induced hypoxaemia upon $\mathrm{CBF}$ in animals under inhalational anaesthesia.

The present study was undertaken to determine the effect of hypoxaemia upon $\mathrm{CBF}$ at two levels of anaesthesia with methoxyflurane.

\section{METHODS}

Beagle dogs whose weight ranged from 9-15 $\mathrm{kg}$ were anacsthetised with pentobarbitone $(30 \mathrm{mg} / \mathrm{kg})$ intravenously and intubated with a cuffed endotracheal tube. A femoral artery and vein were catheterised and the arterial catheter advanced into the thoracic aorta. The venous catheter was placed in the right atrium.

The vertebral artery was cannulated either directly via the internal mammary artery or from a femoral artery using the Seldinger technique.

Arterial pressure was measured continuously by means of a Bell and Howell transducer and Beckman Dynograph recorder; EEG was recorded throughout. A three-way tap attached to the aortic catheter permitted the withdrawal of blood for blood gas analysis and estimation of cardiac output by means of a Waters cuvette and densitometer, cardio-green dye being used as indicator.

The dogs were placed on a heating blanket to maintain temperature close to $35^{\circ} \mathrm{C}$. They werc then paralysed with a single dose of succinylcholine chloride $(1.5 \mathrm{mg} / \mathrm{kg})$ and ventilated for 30 minutes with air and sufficient methoxyflurane from a Pentec vaporizer to produce end-tidal values of 0.3 per cent in four dogs and 0.6 per cent in another four dogs. The Harvard Respiratory Pump was set to deliver a tidal volume of $200 \mathrm{ml}$ and end-tidal carbon dioxide concentration was maintained at a constant level by varying the respiratory rate.

Cerebral blood flow was measured and calculated by the technique previously described. ${ }^{4}$

Cardiac output was measured before and after each injection of ${ }^{133} \mathrm{Xe}$ and arterial blood samples analysed at regular intervals for $\mathrm{pH}, \mathrm{Pco}_{2}$, and $\mathrm{Po}_{2}$. The blood gas results were corrected for temperature change. Arterial hypoxaemia was then induced by ventilating the dogs at the same tidal volume with a mixture of 10 per cent oxygen in nitrogen. The ventilator rate was adjusted to produce arterial carbon dioxide tensions similar to those obtained during ventilation with

* From the Research Institute, The Hospital for Sick Children, and Departments of Anaesthesia, Paediatrics, and Medical Biophysics University of Toronto. 
air. After 15 minutes, when arterial oxygen tensions remained steady at a low level and cardiac output was stable, cerebral blood flow was measured as before.

Cerebral blood flow was again measured in two of the dogs after ventilation with air for 45 minutes following the hypoxic period.

\section{Results}

The cerebral blood flow (CBF) of the four dogs studied at the lower end-tidal concentration of methoxyflurane, increased from $34.5 \mathrm{ml} / 100 \mathrm{~g} / \mathrm{min}$ on air to 75.5 $\mathrm{ml} / 100 \mathrm{~g} / \mathrm{min}$ during the period of hypoxaemia. End-tidal methoxyflurane concentration increased from 0.30 per cent (equivalent to $1.48 \mathrm{MAC}$ at $34.2^{\circ} \mathrm{C}$ ) to 0.31 per cent (equivalent to $1.64 \mathrm{MAC}$ at $33.7^{\circ} \mathrm{C}$ ), during the same period (Tables I and II).

Mean arterial carbon dioxide tension $\left(\mathrm{PaCO}_{2}\right)$ increased by $1.5 \mathrm{~mm} \mathrm{Hg}$ and $\mathrm{pH}$ fell from 7.36 to 7.34 . Cardiac output increased from $1.77 \mathrm{~L} / \mathrm{min}$ to $2.7 \mathrm{~L} / \mathrm{min}$ while the $\mathrm{Po}_{2}$ fell from $70 \mathrm{~mm} \mathrm{Hg}$ to $24.7 \mathrm{~mm} \mathrm{Hg}$ and mean arterial blood pressure (MABP) rose by $23 \mathrm{~mm} \mathrm{Hg}$ from control level of $107 \mathrm{~mm} \mathrm{Hg}$.

In the four dogs studied at the higher concentration of methoxyflurane (Tables III and IV), CBF did not increase to the same degree. At mean end-tidal methoxyflurane level of 0.605 per cent (equivalent to $3.1 \mathrm{MAC}$ at $33.5^{\circ} \mathrm{C}$ ) on air, the mean value for CBF was $34.4 \mathrm{ml} / 100 \mathrm{~g} / \mathrm{min}$. and during hypoxaemia at mean-end tidal methoxyflurane value of 0.655 per cent (equivalent to $3.35 \mathrm{MAC}$ at $33.75^{\circ} \mathrm{C}$ ) the mean value for CBF was $39.5 \mathrm{ml} / 100 \mathrm{~g} / \mathrm{min}$. Cardiac output and MABP increased in two dogs and decreased in the others and $\mathrm{pH}$ and $\mathrm{PaCO}_{2}$ remained unchanged during the period of hypoxaemia in which $\mathrm{PaO}_{2}$ fell from $75 \mathrm{~mm} \mathrm{Hg}(\mathrm{SD} \pm 3.7$ ) to $27 \mathrm{~mm} \mathrm{Hg}$ ( $\mathrm{SD} \pm 1.2$ ).

During the period of recovery CBF cardiac output and MABP were reduced below control levels in the two dogs studied (Table V).

\section{Discussion}

McDowall ${ }^{5}$ has shown that the cerebral blood flow does not respond significantly to changes in arterial oxygen tension $\left(\mathrm{PaO}_{2}\right)$ until a tension of $50 \mathrm{~mm} \mathrm{Hg}$ is reached. Thereafter there is a steady increase in $\mathrm{CBF}$ until at $\mathrm{PaO}_{2}$ in the region of $30 \mathrm{~mm} \mathrm{Hg}$ there is a marked increase. Care was taken, therefore, to ensure that the $\mathrm{PaO}_{2}$ was maintained at levels below $30 \mathrm{~mm} \mathrm{Hg}$ during the period of hypoxia in order to gain maximal increases in CBF under hypoxic stimulus. The dogs were maintained as close to a steady state as possible during the measurement of cerebral blood flow. Although arterial carbon dioxide tensions $\left(\mathrm{PaCO}_{2}\right)$ would appear to have little effect during severe hypoxia since vasodilation is maximal, ${ }^{6}$ the $\mathrm{PaCO}_{2}$ and $\mathrm{pH}$ were maintained close to control values by adjusting the ventilation. Although the temperature was below the normal values it did not alter significantly during the period of hypoxia. It proved extremely difficult to maintain a steady state in the dogs anaesthetised with the higher concentration of methoxyflurane, and in two dogs the measurements were made at a time when cardiac output and arterial blood pressure were falling. 


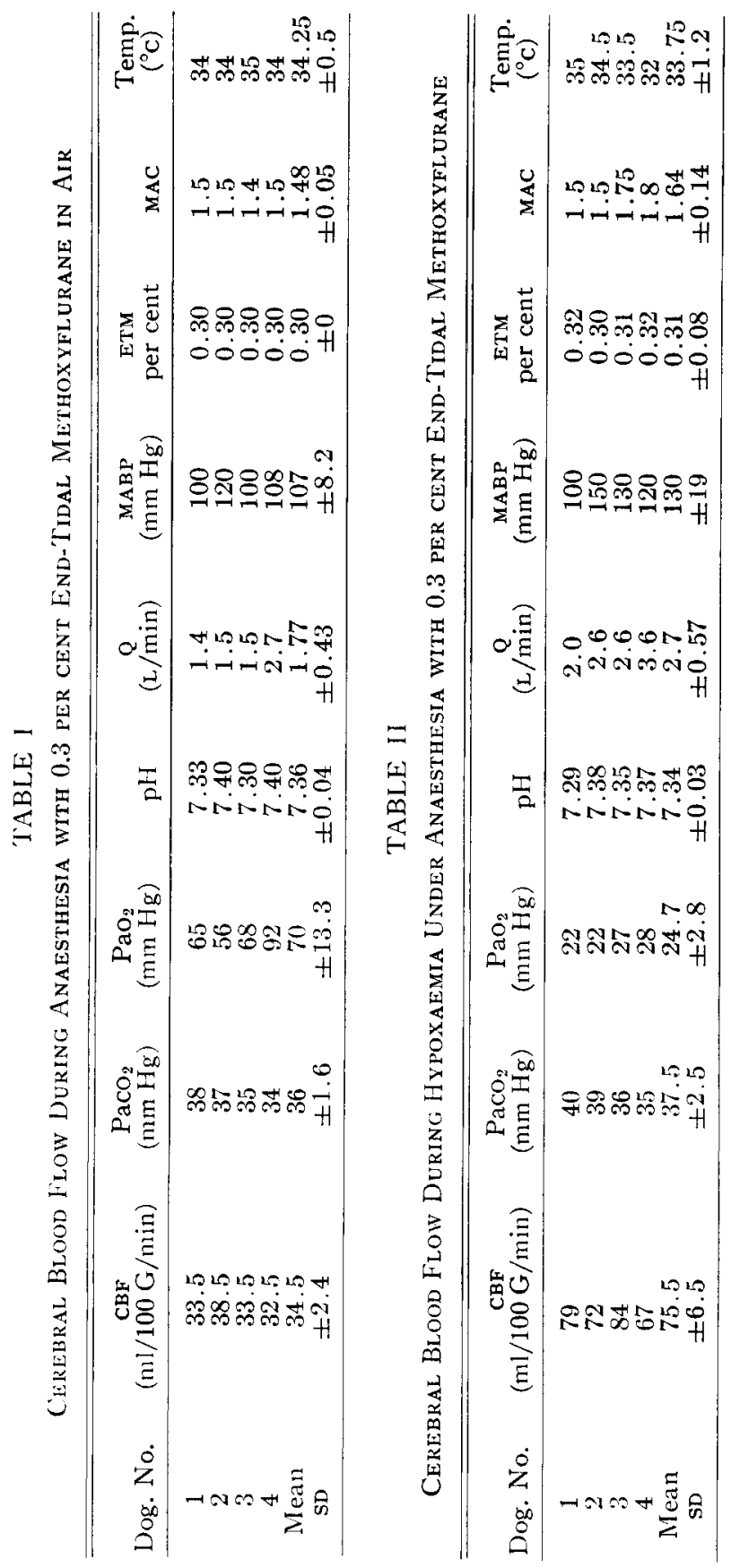



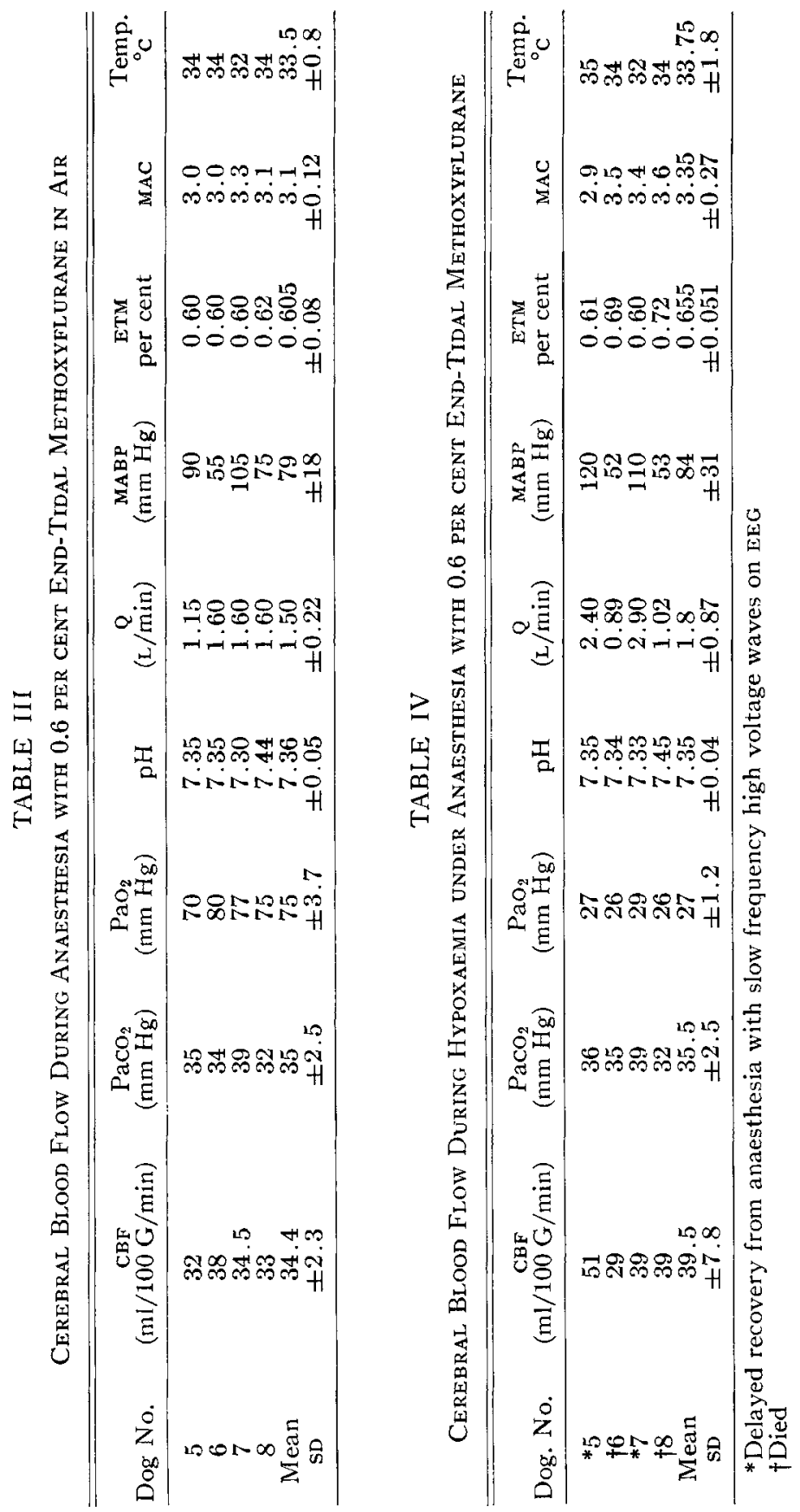
TABLE $V$

Cerebral Blood Flow During the Period of Recovery from Hypoxia

\begin{tabular}{cccccccc}
\hline \hline Dog. No. & $\begin{array}{c}\mathrm{CBF} \\
(\mathrm{ml} / 100 \mathrm{G} / \mathrm{min})\end{array}$ & $\begin{array}{c}\mathrm{PaCO}_{2} \\
(\mathrm{mmHg})\end{array}$ & $\begin{array}{c}\mathrm{PaO}_{2} \\
(\mathrm{mmHg})\end{array}$ & $\mathrm{pH}$ & $\begin{array}{c}\dot{\mathrm{Q}} \\
(\mathrm{L} / \mathrm{min})\end{array}$ & $\begin{array}{c}\mathrm{MABP} \\
(\mathrm{mmHg})\end{array}$ & $\begin{array}{c}\mathrm{Temp} \\
{ }^{\circ} \mathrm{C}\end{array}$ \\
\hline 7 & 33.7 & 39 & 73 & 7.31 & 1.32 & 60 & 32 \\
8 & 26.5 & 30 & 78 & 7.44 & 0.97 & 63 & 34 \\
Mean & 30.6 & 34.5 & $\mathbf{7 5 . 5}$ & 7.37 & 1.15 & 61.5 & 33 \\
\hline
\end{tabular}

It is well known that arterial hypoxaemia leads to cerebral vasodilatation and increased cerebral perfusion. Kety and Schmidt ${ }^{\top}$ found an increase of 35 per cent in cerebral blood flow (CBF) in normal young men exposed to 10 per cent oxygen and Häggendal and Johansson ${ }^{8}$ demonstrated a 100 per cent increase in CBF when arterial oxygen saturation was reduced from 90 per cent to 20 per cent in dogs anaesthetised with pentobarbitone.

In the present study the group receiving 0.3 per cent $(1.5 \mathrm{MAC})$ methoxyflurane had a significant rise $(p<.001)$ in cerebral blood flow during the period of hypoxia. The increase of 220 per cent (Tables I and II) is similar to increases previously seen by us in dogs anaesthetised with pentobarbitone. Cardiac output and mean arterial blood pressure increased in all four dogs in this group. There were no demonstrable EEG changes during or following the period of hypoxia and recovery was rapid and uneventful. There would appear to be little difference in the effects of profound hypoxia during pentobarbitone and 0.3 per cent methoxyflurane anaesthesia.

In contrast the group receiving the higher concentration of methoxyflurane (Tables III and IV) showed a very variable response to hypoxic stimulus (Figure 1). CBF increased by 70 per cent in one dog, fell to 70 per cent of control values in another, and increased by 20 per cent in the remainder. Cardiac output and MaBP varied in similar fashion, although one dog maintained the increased cerebral perfusion despite a fall in cardiac output and blood pressure. These observations agree with those of $\mathrm{Häggendal}^{9}$ who observed absence of autoregulation in dogs with arterial oxygen saturations below 60 per cent although the initial cerebral blood flow levels were elevated under the hypoxic stimulus. Two of the dogs died following the procedure and the remainder had extremely prolonged recovery time with slow frequency high voltage waves on FEG and severe metabolic acidosis. Table $V$ shows the results obtained from two of the dogs in whom CBF, cardiac output and MABP were measured during the recovery period.

Freeman and Ingvar ${ }^{111}$ described an initial increase in cerebral flow during recovery from a period of severe hypoxia and Harper and $\mathrm{McDowall}^{11}$ have demonstrated the "luxury perfusion" effect lasting for twenty minutes following clamping of the aorta for three to five minutes. We have not observed this effect, possibly because the "recovery" measurements were made forty-five minutes after terminating the hypoxic stimulus. At this time, as might be expected following severe hypoxia, autoregulation of the cerebral vessels has been abolished, and the reduction in CBF below control levels follows closely the fall in cardiac output and blood pressure. 


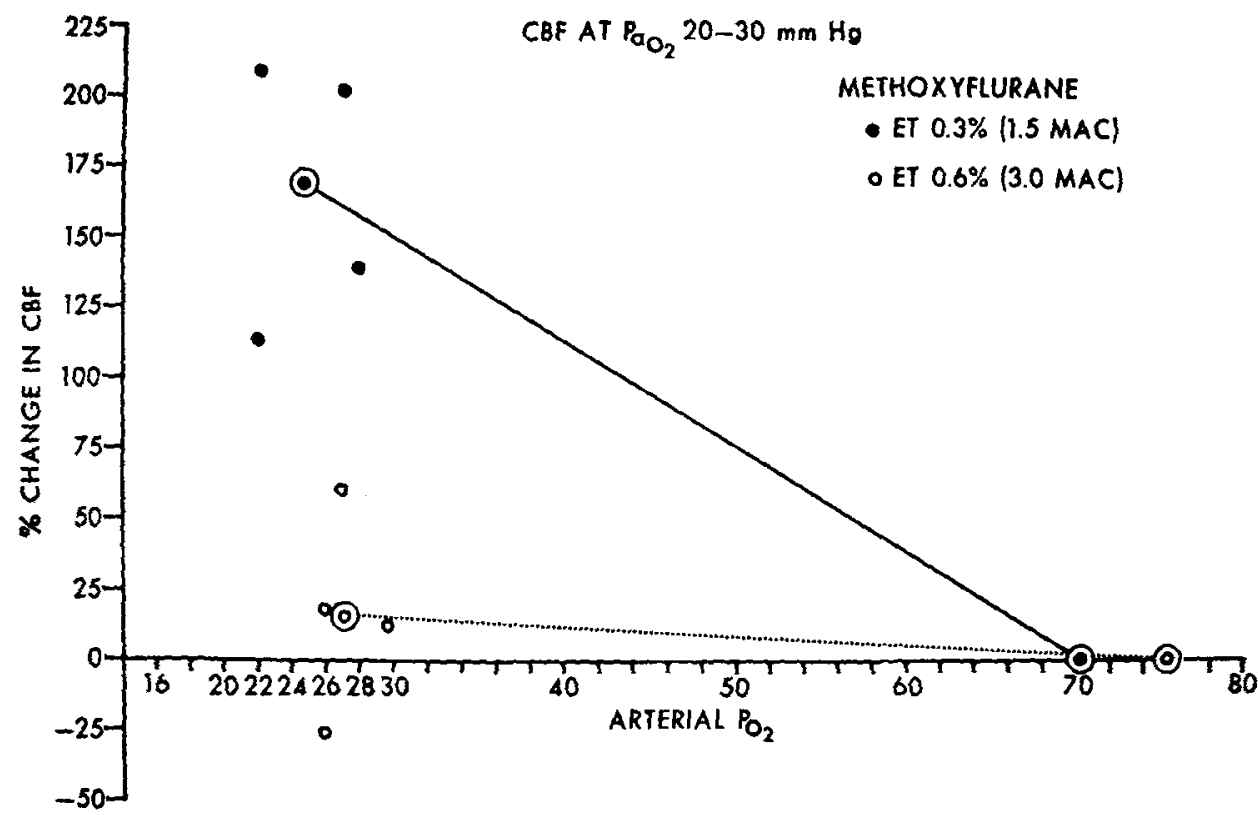

Figure 1. Relationship between percentage change in cerebral blood flow and $\mathrm{PaO}_{2}$ at endtidal methoxyllurane concentrations of 0.3 per cent (closed circles) and 0.6 per cent (open circles).

\section{Conclusion}

At a concentration of 0.3 per cent ( $1.5 \mathrm{MAC}$ ) methoxyflurane, cerebral blood flow, cardiac output, and arterial blood pressure increase normally in response to severe hypoxic stimulus. Cerebral perfusion during the hypoxic episode and on recovery would appear to be adequate.

When the concentration of methoxyflurane is increased to 0.6 per cent ( $3 \mathrm{MAC}$ ) however, the response is extremely variable. Cerebral perfusion, on the grounds of EEG changes and prolonged recovery, is probably not adequate to maintain function.

Further investigation is being carried out with other anaesthetic agents to determine whether the level of anaesthesia, or the agent, is the critical factor.

\section{RÉSUMÉ}

On a mesuré le débit sanguin cérébral chez le chien anesthésié au méthoxyflurane avant, pendant et après l'induction d'une hypoxémie artérielle prononcée.

A la fin de l'expiration, durant l'hypoxie, le débit sanguin cérébral a augmenté de 240 pour cent à des niveaux de méthoxyflurane équivalant à $1.5 \mathrm{MAC}$ (concentration alvéolaire minima).

A des niveaux de méthoxyflurane équivalant à $3 \mathrm{MAC}$, la réponse a été très variable : deux chiens ont eu une augmentation de 20 pour cent, un chien a eu une augmentation de 70 pour cent et un autre a eu une diminution de 30 pour cent dans le débit sanguin cérébral. Le débit cardiaque et la pression artérielle moyenne ont varié de la même façon. 
Dans le dernier groupe, la guérison de l'hypoxie a été retardée et l'électroencéphalogramme a montré une évidente insuffisance de circulation cérébrale.

Il faut conclure que la circulation cérébrale répond normalement au stimulant hypoxique durant l'anesthésie au méthoxyflurane à faible concentration mais qu'elle est probablement insuffisante durant l'anesthésie à concentration plus élevée.

\section{ACKNOWLEDGMENTS}

We are indebted to Dr. P. McDonald of the Department of Radiology, for his valuable assistance with the technique of vertebral artery cannulation and to Dr. E. Echevarre for his help with the surgery. We should also like to thank Dr. W. Zingg and his staff for the use of the facilities in the Animal Research Laboratories.

\section{REFERENCES}

1. Harper, A. M. \& GLass, H. I. Effects of alterations in arterial carbon dioxide tensions on the blood flow through the cerebral cortex at normal and low arterial blood pressure. J. Neurol. Neurosurg. \& Psychiat., 28: 449 (1965).

2. Cohen, P. J.; Alexander, S. C.; \& Wollman, H. Effects of hypocarbia and of hypoxia with normocarbia on cerebral blood flow and metabolism in man. Scand. J. Lab, and Clin. Invest., (Suppl. 102): IvA (1968).

3. Courtice, F. C. The effect of oxygen lack on the cerebral circulation. J. Physiol., 100: 198 (1941).

4. Gray, I. G.; Mitra, S. K.; Nisbet, H. I. A.; Aspin, N.; \& Cheighton, R. E. The effect of methoxyflurane on cerebral blood flow in the dog. Canad. Anaesth. Soc. J., 18: 4 (1971).

5. McDowall, D. G. Inter-relationships between blood oxygen tensions and cerebral blood flow in oxygen measurements in blood and tissues. London: Churchill, J. P. Payne and D. W. Hill ed. (1966) p. 205.

6. Noell, W. \& Schnewer, M. Uber die Durch blutung und die Sauerstoffversorgung des Gehirns, rv. Die Rolle der Kohlensaure. Pflunger, Arch. Ges. Physiol., 247: 514 (1944).

7. Kety, S. S. \& Schmidt, C. F. The effects of altered arterial tensions of carbon dioxide and oxygen on cerebral blood flow and cerebral oxygen consumption of normal young men. J. Clin. Invest., 27: 484 ( 1948).

8. Häggendal, E. \& Johansson, B. Effects of arterial carbon dioxide tension and oxygen saturation on cerebral blood flow autoregulation in dogs. Acta. Physiol. Scand,, 66: Suppl. 258, 27 (1965).

9. HÄGGENDAL, E. Blood flow autoregulation of the cerebral grey matter with comments on its mechanism. Acta. Neurol. Scand., (Suppl. 14) : 104 (1965).

10. Freeman, J. \& Ingvar, D. H. Elimination by hypoxia of cerebral blood flow and eEG relationship. Exp. Brain Res., 5: 61 (1968).

11. Harper, A. N. \& McDowall, D. G. Luxury perfusion. Scand. J. Lab. and Clin. Invest., (Suppl. 102): х в (1968). 